Article

\title{
An Adaptive Basin Management Rule to Improve Water Allocation Resilience under Climate Variability and Change-A Case Study in the Laja Lake Basin in Southern Chile
}

\author{
Enrique Muñoz ${ }^{1,2, *}$, Christian Guzmán ${ }^{3,4}$, Yelena Medina ${ }^{1,2}$, Jan Boll ${ }^{3} \mathbb{D}$, Victor Parra ${ }^{5}$ and \\ José Luis Arumí 5 (D) \\ 1 Department of Civil Engineering, Universidad Católica de la Santísima Concepción, \\ Concepción 4090541, Chile \\ 2 Centro de Investigación en Biodiversidad y Ambientes Sustentables CIBAS, Concepción 4090541, Chile \\ 3 Department of Civil and Environmental Engineering, Washington State University, \\ Pullman, WA 99164-2910, USA \\ 4 Department of Civil and Environmental Engineering, University of Massachusetts, Amherst, MA 01002, USA \\ 5 Department of Water Resources, Universidad de Concepción, Chillán 3812120, Chile \\ * Correspondence: emunozo@ucsc.cl; Tel.: +56-41-2345355
}

Received: 25 July 2019; Accepted: 15 August 2019; Published: 20 August 2019

\begin{abstract}
Due to population growth and expansion in the agricultural and industrial sectors, the demand for water has increased. However, water availability in some regions has decreased due to climate change trends and variability, necessitating innovative strategies and adaptation in water allocation to avoid conflicts among users in a hydrological system. This paper presents a resilience analysis and a conceptual hydrological modeling approach to evaluate the resilience capacity of a new water allocation rule in the Laja Lake basin in southern Chile. Resilience assessments included absorptive and adaptive capacities with four system states: resilient, susceptible, resistant, and vulnerable. A modeling approach was used considering the climate variability uncertainty and climate change trends of the Laja system. Characterization of adaptive and absorptive capacities showed that the Laja Lake basin moved from resistant to vulnerable. Hydrological modeling analyses showed that after a new water allocation agreement, the Laja Lake system is moving from vulnerable to susceptible, since the new rule has more adaptive alternatives to face climate variability. The new rule diminishes the possibilities of conflicts among users, ensuring the fulfillment of water needs for uses such as farming and ecosystem services such as landscaping, and allows for increased water allocation for energy in wet hydrological years.
\end{abstract}

Keywords: water allocation; hydrological modeling; basin resilience

\section{Introduction}

Due to population growth and expansion in the agricultural, energy, and industrial sectors, the demand for water has increased dramatically around the globe [1,2]. In many countries, water laws and management practices apply categories such as "winter water" and "surplus flow" to determine who can use specific quantities of water and when they can use it. But the effectiveness of water allocation rules can vary widely due to the influence of local contexts and hydrological regimes, making it difficult to establish a general rule regarding which specific allocation stipulations are more suitable to address water variability [3]. In addition, climate variability and change have had various effects on water resources [4,5], and these effects may even increase in the coming years [6]. Two of the most 
common climate change impacts described in the literature are precipitation and temperature trends and timing shifts [7]. In addition, the effect of climate variability caused by the El Niño Southern Oscillation (ENSO) phenomenon is greater than climate change trends [8], and therefore major impacts and uncertainty in water resources availability, timing, and variability are expected in the future.

Uncertainty in water allocation and modeling is an ongoing challenge under study (e.g., [9]). It can be associated with model parameters, structure, and/or input variables [10,11]. Beven [12] presented the equifinality thesis, which recognizes the existence of different parametrizations or model structures that can equally represent the modeled system. Thus, a single model cannot easily be chosen, and a range of behavioral models (structures and parameterizations) might represent parametric and structural uncertainty. This range mainly reflects that our understanding (or lack of understanding) is uncertain due to model representation, data, parameter estimation, and model structure [13], resulting in uncertainty in the predictions made by the model. On the other hand, there is also uncertainty in the predictions made to force hydrological models (uncertainty related to the input variables). Such uncertainties can be related to the climatic model itself or to the nature of the climatic variables being predicted. Including such uncertainties is therefore crucial for decision making and water management processes, especially in areas highly affected by natural and anthropogenic variability such as climate variability and change.

Challenged by the numerous water conflicts caused by the imbalance between water supply and demand, the question of how to allocate water resources between various demands during shortage periods has become a critical issue and has attracted much attention from water managers and researchers worldwide $[14,15]$.

Many optimization techniques for water allocation have been proposed such as linear, non-linear, and dynamic programming, genetic algorithms, and artificial neural networks [16-20]. Normally, however, water resource systems have complexities in terms of social, economic, and natural resources and environmental aspects [21], which lead to the development of multi-objective models and the incorporation of uncertainties in the future availability of water in research studies. For example, Islam et al. [22] investigated the overall management of South Saskatchewan River basin water resources subject to possible changes in climate-change-related impacts projected by climate scenarios combined with active ENSO episodes by the 2050s. Culley et al. [23] developed an approach to identify the maximum operational adaptive capacity of water resource systems with respect to a future climate exposure space based on general circulation models and regional climate models under representative concentration pathways.

Since optimization mostly provides a mathematical relationship between economics and engineering, fair water allocation alone is not sufficient for future scenarios. In order to improve water security and its allocation, therefore, a resilient system must be pursued. System resilience concepts have been part of the civil engineering and water resources literature for some time [24-28] and they have been widely used as an approach to study the dynamics of complex adaptive systems and their uncertainty [29]. Hydrological resilience in a water resource system can be seen as the ability to maintain structure and function after a disturbance [26,30-34]. Fiering and Holling [30] highlighted recovery time, boundaries, and failure as key concepts within water systems, and Hashimoto et al. [32] quantitatively incorporated these concepts into system performance measures (failures, reliability, resiliency, and vulnerability). The quantitative determination of resilience can provide various benefits such as understanding and comparing system resilience under different environmental, organizational, social, and economic conditions [35]. On this basis, Asefa et al. [36] applied the evaluation of resilience in a water resources system under changing future climatic conditions and water supply conditions, while Chanda et al. [37] analyzed spatial and temporal variation of resilience to characterize long-term drought.

There are several frameworks for measuring resilience. For example, 10 resilience frameworks covering ecological, developmental, and social-ecological resilience are summarized in Quinlan et al. [34]. Most of them acknowledge that people and ecosystems form an integrated 
social-ecological system. A common objective of resilience assessment is to identify risks, opportunities, and alternatives to conventional management strategies. It emphasizes the measurement of statistical signals and identification of thresholds. Mao et al. [38] proposed a novel complement described as a "resilience canvas," which is a heuristic device to identify possible pathways and facilitate the design of bespoke strategies for enhancing resilience in the socio-hydrological context.

As the resilience assessment builds upon both adaptive management [39] and participatory approaches to learning and acting [40], this study builds on the resilience management concept [38] to evaluate the resilience resulting from a new water allocation rule in the Laja system in southern Chile. Mao et al. [38] proposed a resilience canvas to identify possible pathways and facilitate the design of strategies for enhancing resilience in a socio-hydrological system and sustaining hydrological ecosystem services. In this regard, two main resilience terms were considered-the adaptive and absorptive capacity of the system. Adaptive capacity synthetizes the capacity of the system to adapt to new (possibly unknown) conditions. Absorptive capacity, on the other hand, summarizes the capacity of the system to receive impacts without moving to a vulnerable state. It includes, for example, the capacity to support droughts and deliver water regularly for human activities, among others. As a result of these two concepts, a system can be classified as (1) resistant (highly absorptive, low adaptive), (2) susceptible (low absorptive, highly adaptive), (3) vulnerable (low absorptive, low adaptive), or (4) resilient (highly adaptive, highly absorptive) [38].

The objective of this study is to analyze if and how a new water allocation rule can improve the resilience of the Laja River basin hydrological system (Chile). To this end, we use a climate variability and change scenario and a hydrological modeling approach. To evaluate system resilience, the adaptive and absorptive capacities of the system are characterized considering climate change trends and uncertainty caused by climate variability.

\section{Methods}

\subsection{Study Area and Context}

The Laja River basin $\left(36^{\circ} 52^{\prime} \mathrm{S}-72^{\circ} 38^{\prime} \mathrm{W}\right.$ and $\left.37^{\circ} 39^{\prime} \mathrm{S}-71^{\circ} 12^{\prime} \mathrm{W}\right)$ encompasses around $4668 \mathrm{~km}^{2}$ on the western slope of the Andes Mountains in southern Chile and is bounded by the Andes and the Nevados de Chillán stratovolcanoes. The basin has a temperate snowmelt dominated headwater system (the Laja Lake basin) that feeds a reservoir storage system for energy production and irrigation.

The climatic patterns in the area generate mainly frontal rainfall. On the western face of the Andes, rainfall enhancement occurs mainly due to orographic effects over the Andes Mountains [41]. This region receives mean annual precipitation of between $1100 \mathrm{~mm}$ at the basin outlet (in the Central Valley) to over $2300 \mathrm{~mm}$ at the headwaters. In the Laja Lake basin, snowfall is concentrated in the coldest months of the year (June to August), accounting for $47 \%$ of total annual precipitation. The Laja Lake basin presents a snow-dominated hydrological regime whose outflows are regulated by the lake.

In addition, the study area is highly influenced by the ENSO and Pacific Decadal Oscillation (PDO) phenomena. ENSO is a coupled ocean-atmosphere phenomenon, characterized by irregular fluctuations (2-7 years periodicity), whereas the PDO is a pattern of Pacific climate variability similar to ENSO in character, but varies over a longer time scale (remaining in the same phase for up to 20 to 30 years). The PDO, which, like ENSO, consists of a warm and cool phase, alters upper level atmospheric winds and can have significant global climate implications, favoring droughts and flooding around Pacific basins. In the Laja River basin, ENSO and the PDO are a major source of interannual variability and are related to below/above normal precipitation and higher-/lower-than-normal air temperatures [41,42].

The Laja Lake sub-basin $\left(975 \mathrm{~km}^{2}\right)$ at the headwaters of the Laja River basin (Figure 1) is a depression of Andean volcanic soils with low permeability [43]. Steep slopes dominate the topography and the soils are volcanic and sandy. The lake has two outflows, a natural one that consists of seepage through fractured rocks, giving rise to the Laja River, and an anthropogenic one in the form of the El Toro 
Hydroelectric Plant tunnel, which connects the lake with the Polcura River and whose flows vary according to energy and irrigation demands (Plant Tunnel shown in Figure 1).

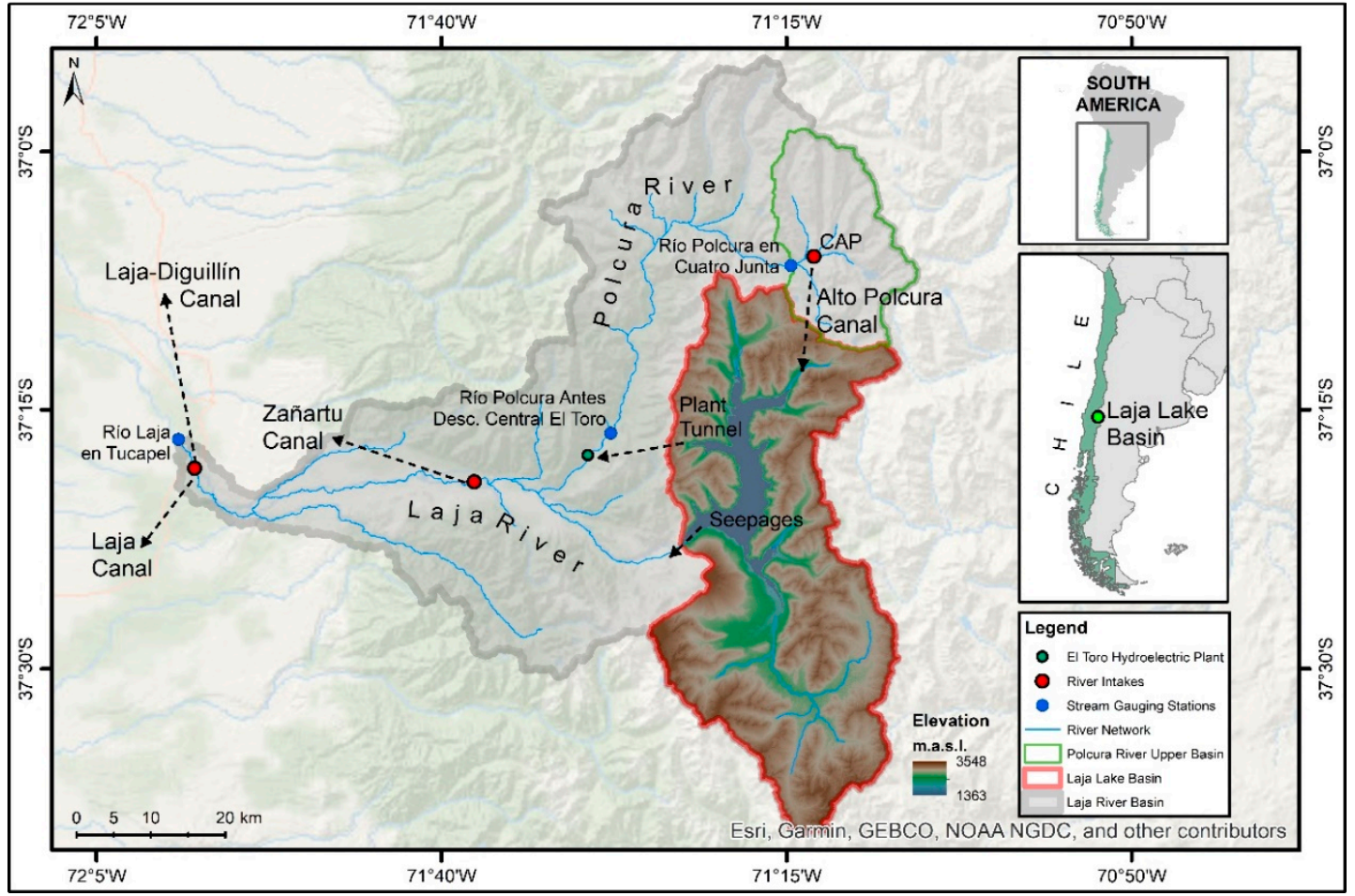

Figure 1. The Laja Lake basin and digital elevation model. Blue lines indicate the river network while blue, red and green points indicate reference locations for the hydrometric stream gauging stations, canal intakes, and the discharge point of El Toro Plant, respectively.

Demand for water from the lake has evolved over time. Before 1960, the lake was completely natural, and its natural regulation capacity was used by farmers downstream though two main irrigation canals, Laja and Zañartu canals (see location in Figure 1). The lake provided (via seepage) over $45 \mathrm{~m}^{3} / \mathrm{s}$ in the summer and maintained a level around $1365 \mathrm{~m}$ above sea level (m.a.s.l.). After 1960, the lake was depleted to build the El Toro hydroelectric plant (see the lake level record in Figure 2) and was transformed from a natural lake into a managed one. In 1977, the Alto Polcura Intake (Captación Alto Polcura, CAP) was built to move water from the upper Polcura River to the lake for the purpose of energy production.

With the construction of the El Toro hydroelectric plant, Laja Lake was "converted" to the largest reservoir in the country. Since then, the lake and its water allocation have historically been managed according to the Riego-ENDESA (1958) agreement [44] between the National Irrigation Directorate (today the Public Works Ministry) and the Empresa Nacional De Energía S.A. (ENDESA). The agreement regulated the allocation of water from Laja Lake for irrigation and energy according to users' water rights. Water allocation and restrictions were traditionally applied based on predictions and water availability in the lake.

More recently, a new demand was added to the system by way of a transboundary canal (the Laja-Diguillín canal) located downstream of the lake in the Laja River. This canal increased demand for lake water for irrigation in a neighboring basin. Overall, water demand has increased over time due to the incorporation of the Laja-Diguillín Canal (which started to transfer water from the Laja River in 2001), as well as climate change trends and population growth. Precipitation in the study area has decreased due to climate change trends [45], and therefore the supply has been dwindling, while temperature-warming trends are associated with more evaporation and, in turn, greater water 
needs for agriculture. Population growth, meanwhile, has increased energy demand, resulting in a greater need for water from the lake.

In the first three decades since El Toro began operating in 1973, there were no conflicts among users, mainly because the lake levels were adequate to meet water demands (the initial operating state of the lake was about $3500 \mathrm{Hm}^{3}$ ). However, during the last 15 years, conflicts among users have occurred, and they have increased in number during the last decade. The origin of the recent conflicts may be the 2010-2016 drought in Chile [46], but the resilience capacity (or vulnerability) of the lake also was affected by the gradual yet constant reduction of its absorptive capacity.

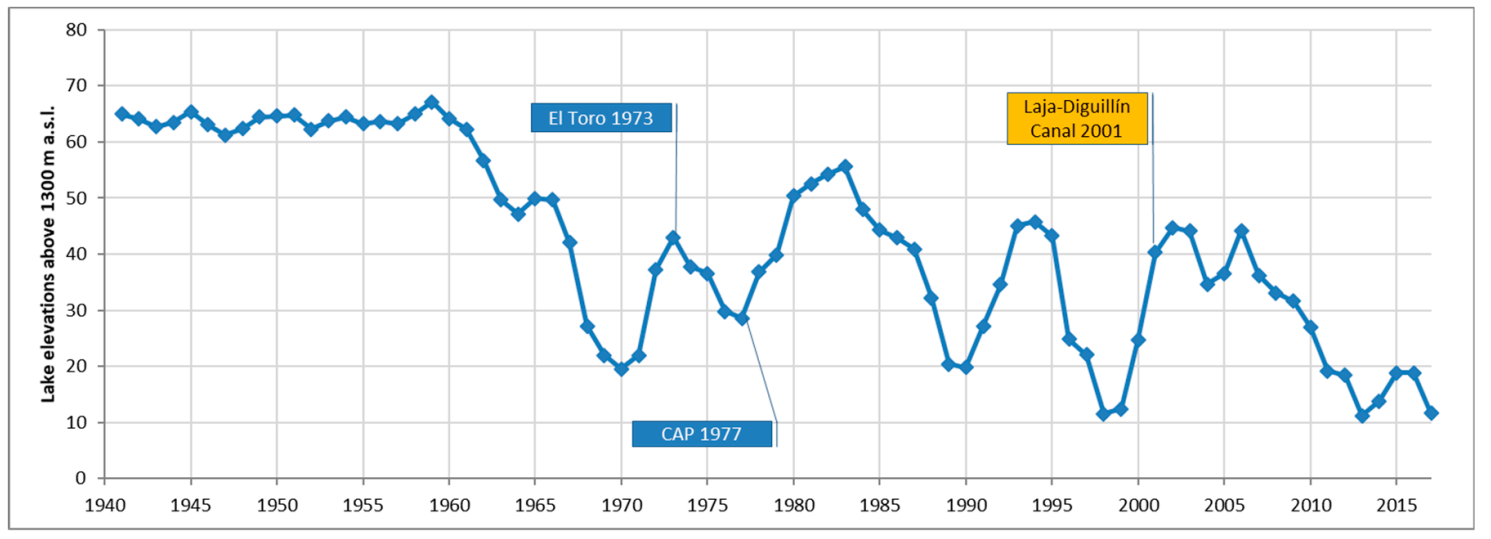

Figure 2. Laja Lake mean annual elevation above a reference of 1300 m.a.s.l. Blue text boxes indicate when anthropogenic changes were made to the lake basin (as explained in the text), and the orange text box indicates when a new demand for lake water (for irrigation) was added.

During the last several years, concurrent conflicts among tourists, farmers, and energy users have greatly increased awareness of the depletion of the lake, which reached its lowest recorded levels (below $600 \mathrm{Hm}^{3}$ ), triggering the need for a new agreement to provide water, security, and ecosystem services such as for ecological, tourism and landscaping purposes. Ecosystem services were not initially considered in the regulation agreement, and, for example, neither Laja Falls nor the lake ecosystem were granted water rights. Amid this increased tension, in 2018, a new agreement was reached [47], which sought to (1) increase the current lake levels in order to give more security to its users, especially for irrigation, (2) increase flexibility in water allocation in order to adapt to the ongoing climatic scenarios and reduce conflicts, and (3) include social and ecological system services, thus avoiding non-desirable states. To analyze the resilience capacity resulting from the proposed rule, a conceptual modeling approach was used.

\subsection{Description of the Former and New Operation Rule}

The operation rule in the 1958 Riego-ENDESA agreement considered allocation of water for irrigation and energy annually at the end of November according to each user's water rights and the availability of water from the lake plus the weather forecast for the coming season made by the local water authority. In terms of estimating existing water availability, the only restriction was that, within a year, users could not divert more water than they had rights to. In case of restrictions due to limited lake storage, water was distributed proportionally according to their water rights.

Prior to the 2018 agreement [47], several operation rules and modeling scenarios were tested. Among the most critical ones and the conclusions reached are the following:

(i) Simulation of continuing under the current operation rule for water allocation: The 1958 agreement led to the current situation of the lake. Simulations showed the existence of an overallocation of water. Therefore, continuing under this water allocation rule would generate more conflicts among users, lower lake levels and greater uncertainties. 
(ii) Allocation based on predictions. The 1958 allocation rule was based on the prediction of the next hydrological year. However, such predictions are subject to high uncertainty due to climate variability and would constantly cause the overexploitation of the lake.

(iii) Allocation based on current water availability. This analysis helped bring about a turning point in the discussion on a new agreement. Simulations of water allocation based on current water availability (not predictions) showed that system stability could be reached. From this point forward, the level of stability pursued was discussed.

(iv) Lake stability and water security for Laja Lake users. Once a lake stability criterion was defined (point iii), the discussion moved to water security and priority of uses. As water for irrigation and other purposes is also used for energy, irrigation and tourism were seen as the most sensitive-to-conflict water uses. In addition, irrigation requires minimum water allocation security in order to plan investments and crops. Therefore, a minimum base of water allocation for irrigation and landscape (tourism) uses was defined, and after covering this minimum, a combined allocation for energy and irrigation was agreed upon. In the case of wet hydrological years and abundant water availability in the lake for water allocation, more water for energy would be allocated in order to not restrict energy production under favorable conditions.

The 2018 rule considers water allocation according to the diagram shown in Figure 3. Aimed at creating adaptive capacity, the agreement established that at the end of November water allocation for the upcoming year would be defined only based on its current state. According to the last 20 years of data, the mean annual net recovery (inflows minus seepage and evaporation) of the lake is $1001 \mathrm{Hm}^{3}$. The agreement defined a "lower reservoir" of $1200 \mathrm{Hm}^{3}$, with up to $600 \mathrm{Hm}^{3}$ for farmers to give them the security they need to maintain crops and activities. As the infiltration from the lake is lower at lower water elevations, the recovery rate is greater at lower levels. Therefore, this rule ensures that over $45 \%$ of the net recovery stays in the lake in case of low water levels. In addition, with the "lower reservoir" and "medium reservoir 1" lake-level recovery and sustainability are pursued, keeping around $45-55 \%$ of the net inflows into the lake.

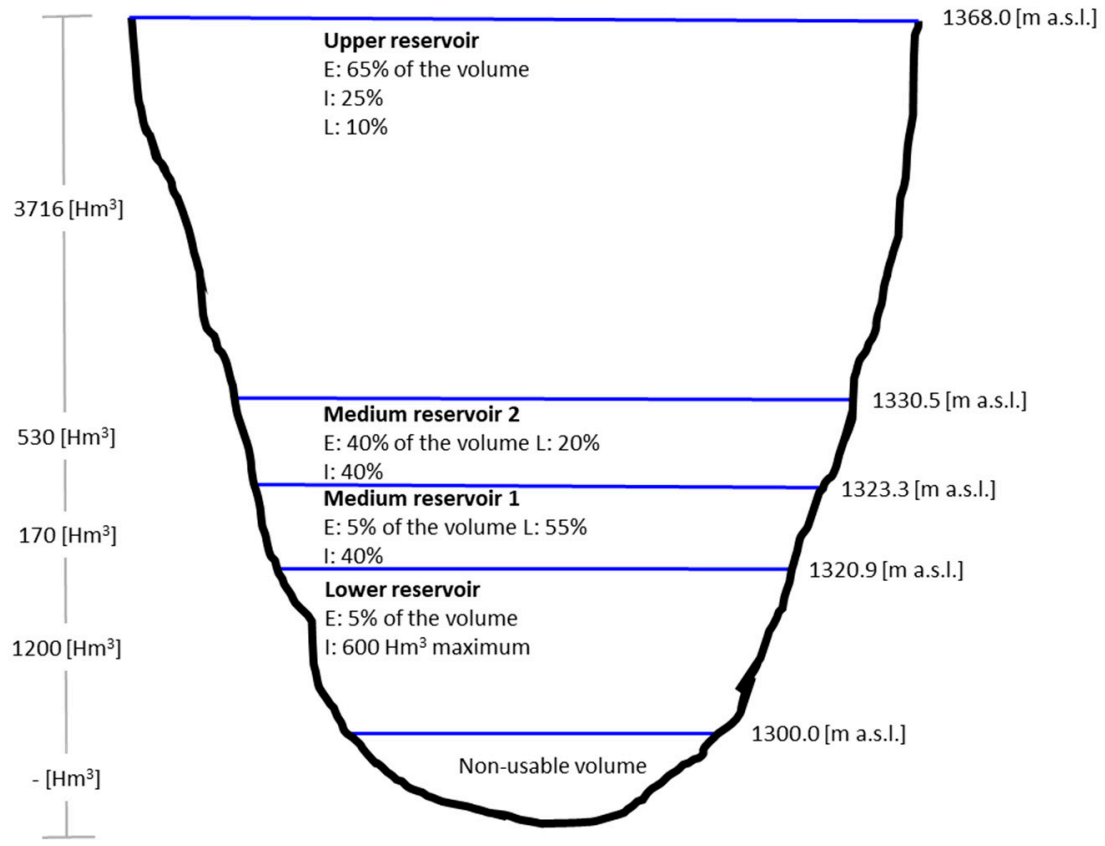

Figure 3. Water allocation diagram of Laja Lake for the upcoming year depending on lake levels on 30 November. E: water for energy; I: water for irrigation and tourism; and L: water that stays in the lake to replenish lake levels and contribute to infiltration/recharge. 
At the "medium reservoir 2" level, water use is equally distributed between energy and irrigation, whereas the "upper reservoir" level offers an adaptive allocation in order to use more water when excess water is available (due to, for example, wet hydrological years).

Complementarily, an amount of water from the lake passing through Laja Falls was committed to in order to supply the social aspects of tourism and landscape preservation. This water was included as irrigation water.

\subsection{Water Balance Model Descrption}

The Muñoz Hydrological Model (MHM) [48] adapted to the Laja Lake basin was used. The MHM model is a monthly snow-rain lumped water balance model (Figure 4) that simulates rainfall-runoff and snowmelt-runoff processes separately and permits inclusion of anthropogenic alterations such as irrigation canals and reservoir operation.

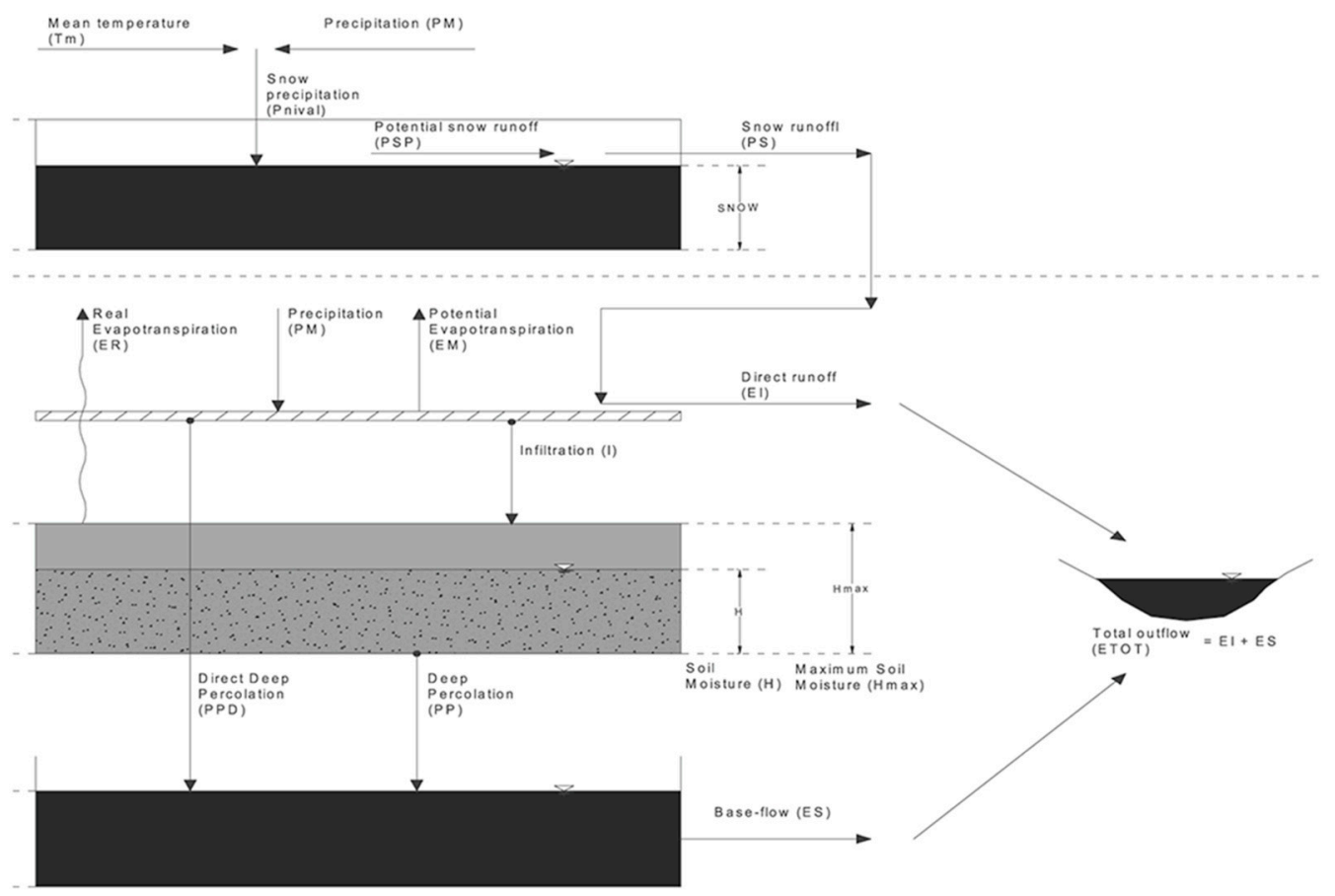

Figure 4. Conceptual diagram of the Muñoz Hydrological Model (MHM) model.

The rainfall-runoff component is modeled through a lumped model that considers the watershed as a double storage system: shallow storage (SS) and underground storage (US). SS represents the water stored in the unsaturated soil layer as soil moisture. US is the water that covers the saturated soil layer. The model requires two inputs-rainfall (PM) and potential evapotranspiration (PET). The model outputs total runoff (ETOT) at the watershed outlet, and includes both subsurface (ES) and direct runoff (EI), the amounts of which are calculated through six calibration parameters, plus two for input modification (A and B, useful in case of non-representative PM and PET data). Factors A and B were used for the study area because climate input data highly depend on ground stations. The Laja Lake basin, however, is a data-scarce area with no ground stations in the basin and only a few stations are located nearby, on the western side of the basin. Most of the rain gauge and temperature stations are located in low- and mid-altitude areas (below 600 m.a.s.l.), and thus the orographic effect and temperature gradient are not adequately measured [49]. To correct the model input variables and ensure the closure of the long-term mass balance, the use of such factors is deemed an appropriate option. Some examples of the application of this method can be found in [49-51].

The snowmelt-runoff model calculates snowfall $\left(\mathrm{P}_{\text {snow }}\right)$ as precipitation falling above the $0{ }^{\circ} \mathrm{C}$ isotherm (base temperature at which melting starts). $\mathrm{P}_{\text {snow }}$ is stored in the snow storage system 
(SN), from which snowmelt is calculated using the degree-day method [52]. Thus, the potential melting (PSP) is estimated, and then, based on the snowpack, the actual snowmelt (PS) is calculated. Next, PS is distributed into the rainfall-runoff model through the snowmelt transference factor $F$. Additionally, to consider sub-monthly variability of the air temperature in the basin, a minimum snowmelt factor (DM), which is defined as a fraction of the snow stored in the basin, is incorporated into the model. Table 1 presents a brief description of the model parameters, their influence on the model and suggested ranges [51].

Table 1. Description of the model parameters, adjustment factors and ranges for the rainfall- and snowmelt-runoff model.

\begin{tabular}{|c|c|c|c|c|}
\hline Module & Parameter & Description & Influence on & Range \\
\hline \multirow{5}{*}{$\begin{array}{c}\text { Rainfall } \\
\text { module } \\
\text { parameters }\end{array}$} & $\mathrm{D}$ & - Percentage of rainfall over $\mathrm{P}_{\mathrm{Lim}}$ transformed into PPD. & $-\mathrm{PPD}$ & $0-100$ \\
\hline & $\mathrm{H}_{\max }(\mathrm{mm})$ & - Maximum capacity of the soil layer to retain water. & $-\mathrm{C}_{\max }$ and $\mathrm{ER}$ & $180-500$ \\
\hline & $\mathrm{C}_{\mathrm{k}}$ & - Underground runoff coefficient. & - ES & $0.05-0.85$ \\
\hline & A & - Precipitation data adjustment factor. & $-\mathrm{PM}$ & $0.80-2.50$ \\
\hline & B & - Potential evapotranspiration data adjustment factor. & - PET and ER & $0.80-2.50$ \\
\hline \multirow{2}{*}{$\begin{array}{l}\text { Snow module } \\
\text { parameters }\end{array}$} & $\mathrm{DM}$ & $\begin{array}{l}\text { - Minimum melting rate when the monthly temperature is } \\
\text { lower than } \mathrm{Tb} \text {. }\end{array}$ & - PSP, PS & $0.00-0.50$ \\
\hline & $\mathrm{F}$ & - Fraction of the real snowmelt that goes to EI. & - EI & $0.00-1.00$ \\
\hline
\end{tabular}

EI: Direct runoff; PPD: Direct deep percolation; ER: Real Evapotranspiration; ES: Subterranean runoff; PM: Precipitation; PET: Potential evapotranspiration; PSP: Potential snowmelt; PS: Real snowmelt.

The model was adapted in order to include the Laja Lake regulation and operation rule. As the MHM is a lumped model, the Laja Lake basin was modeled using a semi-distributed model and was calibrated based on lake elevation records. In addition, as the surface area of the lake changes according to its level, the surface area of each sub-model (lake and precipitation-snowmelt-runoff) varied at every time step according to the lake level. A fixed total basin area was maintained and verified in this setup. Therefore, to simulate the lake system, a new storage system was added where the outputs from the precipitation-snowmelt-runoff modules were considered as inputs to the lake. In addition, all precipitation over the lake was assumed to be rain because solid precipitation melts when it hits the lake's water surface.

Lake outflows were estimated based on the lake level and the rule to be defined as a result of the new agreement for water allocation. Relationships between lake surface area (Equation (1)), volume (Equation (2)) and seepage discharge (Equation (3)) as a function of elevation were obtained from studies and surveys conducted by the Ministry of Public Works [53,54]. Further details of the model and equations can be found in Muñoz et al. [13].

$$
\begin{gathered}
\text { Area }\left(\mathrm{km}^{3}\right)=1.0986 \times \mathrm{H}-1423.8 \\
\text { Volume }\left(\mathrm{Hm}^{3}\right)=0.004 \times \mathrm{H}^{3}-0.8374 \times \mathrm{H}^{2}+379.87 \times \mathrm{H}+124,769 \\
1362<\text { Stage }(\mathrm{H})<1369 \text { m.a.s.l. } \mathrm{QF}=8.44 \times 10-3 \times(\mathrm{H}-1290)^{2.000}
\end{gathered}
$$




$$
\begin{aligned}
& 1340<\text { Stage }(\mathrm{H}) \leq 1362 \text { m.a.s.l. } \mathrm{QF}=9.74 \times 10-2 \times(\mathrm{H}-1370)^{2.000} \\
& 1220<\text { Stage }(\mathrm{H}) \leq 1340 \text { m.a.s.l. } \mathrm{QF}=9.26 \times 10-3 \times(\mathrm{H}-1220)^{2.000}
\end{aligned}
$$

\subsection{Modeling Approach and Data}

For the calibration-validation procedure, Laja Lake levels (i.e., elevations) were used. The calibration was performed using the Kling-Gupta Efficiency (KGE) [55] as the objective function. The KGE index is an improvement over the Nash-Sutcliffe Efficiency (NSE) [56] in which the components of bias, correlation, and variability in the objective function are equally weighted, resolving the systematic underestimation of peak flows and low bias (variability) influence identified in the NSE [55]. Additionally, complementary objective functions such as the RunOff Coefficient Error (ROCE), the Root Mean Squared Error (RMSE), Percentage of BIAS (PBIAS), the coefficient of determination $\left(R^{2}\right)$, and NSE were calculated as a complement for the validation stage. For the objective function equations, please refer to Table 2.

The calibration was performed using Monte Carlo simulations to search for parameter identifiability [57]. Yilmaz et al. [58] defined behavioral models as those with an equally acceptable representation of the system under simulation, which can be classified as models with a performance measure above a threshold of eligibility. According to this definition and in order to obtain the best representation of all such possible combinations, the optimal value of each parameter was chosen according to the 50th percentile in the cumulative distribution function (cdf) of the behavioral models obtained from 10,000 simulations. The number of simulations to cover the entire feasible space of parameter combinations was defined following a prior study with the MHM model (see [13]). The acceptance criterion for validation consisted of KGE values similar to those obtained in the calibration and over 0.6. With the model validated, further simulation and analyses were performed according to the new agreement for water management and allocation.

To study the new water allocation rule and its adaptive and absorptive capacities, a modeling approach incorporating uncertainty and climate change trends was used. As climate variability plays a major role in the study area [59], uncertainty related to it was estimated using Monte Carlo samples and the Generalized Likelihood Uncertainty Estimation (GLUE) [60] method. A total of 10,000 simulations was run with random permutation of the climate records of from January 1980 to April 2014. To include climate change trends, long-term precipitation and temperature records (from 1940 to 2014) for the area near Laja Lake were used. Trends of $-0.2839 \mathrm{~mm} /$ year and $0.0078^{\circ} \mathrm{C} /$ year were derived for precipitation and temperature, respectively, and a trend of $0.1896 \mathrm{~mm} /$ year for potential evapotranspiration was calculated. To define the uncertainty bands, at every time step of the simulation the top and bottom $2.5 \%$ of the model runs were discarded.

To perform the modeling, precipitation and temperature data were obtained from the $0.5^{\circ}$-resolution Global Gridded Dataset published by Willmot and Matsuura [61]. This dataset was validated for the study area in Muñoz et al. [62]. To estimate PET, the Thornthwaite method [63] was used. Lake levels and El Toro flows were provided by the Chilean National Electric Coordinator.

Calibration and validation were performed for two 10-year time windows (1980-1990 and 1990-2000, respectively). Lake-level predictions were calculated starting in 2014 because it was the last year with full data availability (i.e., climatic, lake level and allocation data). It is important to point out that one year (April 2013-March 2014) was used to warm up the simulations. During that period neither water allocation nor uncertainty analysis was performed. 
Table 2. Objective function equations and reference performance rating (subtracted from $[64,65]$ ).

\begin{tabular}{|c|c|c|c|}
\hline \multirow{2}{*}{ Objective Function } & \multirow{2}{*}{ Equation } & \multicolumn{2}{|c|}{ Performance Rating } \\
\hline & & Satisfactory & Very Good \\
\hline KGE & $1-\sqrt{(r-1)^{2}+(\alpha-1)^{2}+(\beta-1)^{2}}$ & $>0.50$ & $>0.90$ \\
\hline NSE & $1-\frac{\sum_{j=1}^{n}\left(Q_{s}-Q_{o}\right)^{2}}{\sum_{j=1}^{n}\left(Q_{o}-\bar{Q}_{o}\right)^{2}}$ & $>0.50$ & $>0.75$ \\
\hline $\operatorname{ROCE}^{*}\left(\mathrm{~m}^{3} / \mathrm{s} / \mathrm{mm}\right)$ & $a b s\left(\frac{\overline{Q_{s}}}{\bar{P}}-\frac{\overline{Q_{o}}}{\bar{P}}\right)$ & - & - \\
\hline $\operatorname{RMSE}^{*}\left(\mathrm{~m}^{3} / \mathrm{s}\right)$ & $\sqrt{\frac{1}{n} \sum_{j=1}^{n}\left(Q_{s}-Q_{o}\right)^{2}}$ & - & - \\
\hline PBIAS (\%) & $\frac{\sum_{j=1}^{n}\left(Q_{s}-Q_{o}\right)}{\sum_{J=1}^{n} Q_{o}}$ & $<|25 \%|$ & $<|10 \%|$ \\
\hline $\mathrm{R}^{2}$ & $\frac{\operatorname{COV}\left(Q_{s}, Q_{o}\right)}{\sigma_{Q_{s}} \times \sigma_{Q_{0}}}$ & $>0.50$ & $>0.75$ \\
\hline
\end{tabular}

$\overline{Q_{s}}$ : Simulated runoff; $Q_{o}$ : Observed runoff; $\overline{Q_{o}}$ and $\overline{Q_{s}}$ : Mean value of observed and simulated runoff, respectively; $\bar{P}$ : Mean annual precipitation. In KGE, $r$ : Pearson correlation coefficient; $\propto$ : Ratio of the simulated and observed standard deviation values; $\beta$ : Ratio between the simulated and observed mean flows. ${ }^{(*)}$ ROCE and RMSE are objective functions that depend on the magnitude of streamflows and basin area. Therefore, reference and generalizable performance ratings may be subject to the study area and problem under research.

\section{Results and Discussion}

Model performance for the calibration and validation phases was very satisfactory (see Figure 5). For the calibration period, NSE was $0.93, \mathrm{R}^{2}$ was 0.97 , and KGE was 0.96 . For the validation period, these statistics were slightly lower but still very good $\left(\mathrm{NSE}=0.92, \mathrm{R}^{2}=0.96\right.$, and $\mathrm{KGE}=0.84$ ). PBIAS improved during the validation period compared to the calibration period ( $0.001 \mathrm{vs.} 0.169)$, while the RMSE decreased slightly from 3.905 to 3.689 . These results show that the behavior of the Lake Basin is well-represented by the water balance model, providing representative outflows for natural seepage and hydroelectric use. 

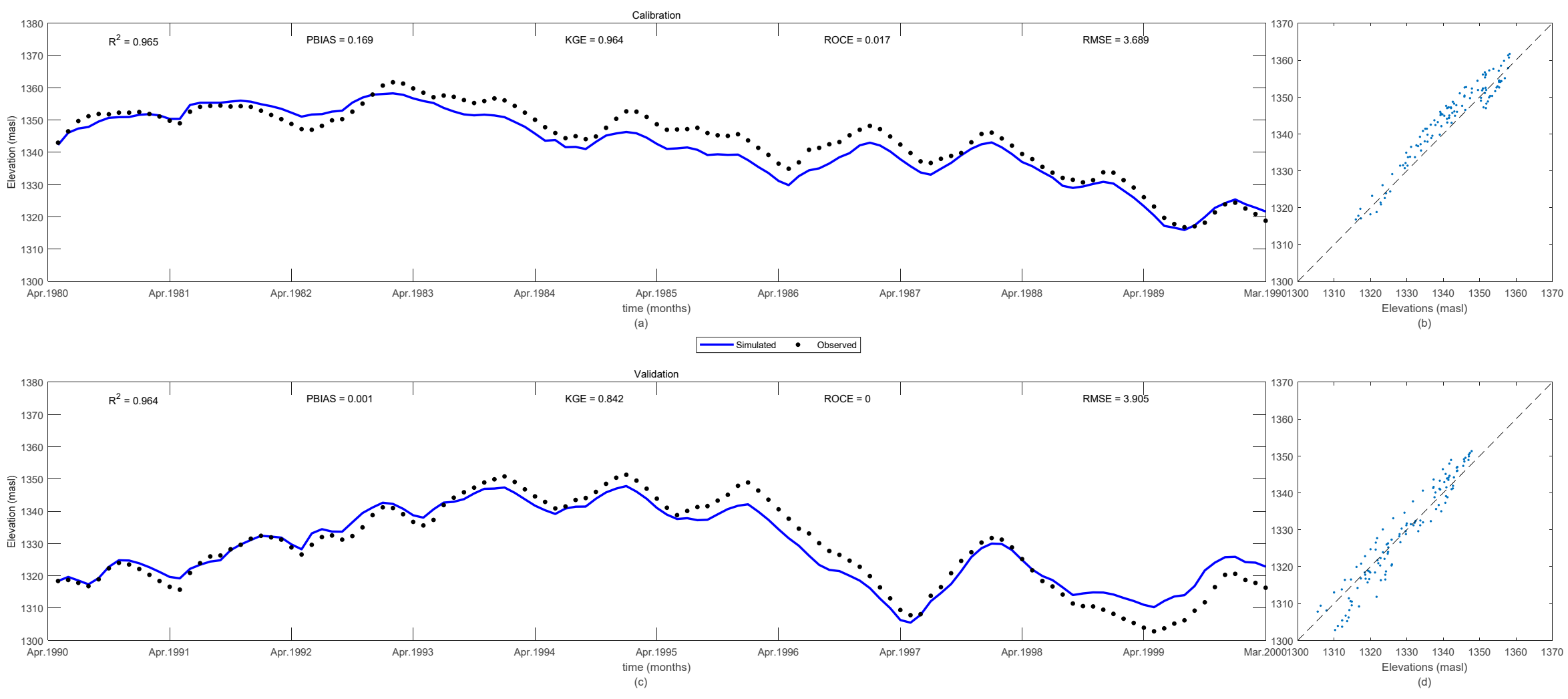

Figure 5. Left panel. Observed (dotted lines) and simulated (blue lines) lake levels (elevations) from April 1990 to March 2000 for the calibration period (a) and the validation period (c). Performance metrics correlation coefficient $\left(R^{2}\right)$, Percentage of BIAS (PBIAS), Kling-Gupta Efficiency (KGE), Run-Off Coefficient Error (ROCE), and Root Mean Squared Error (RMSE) are shown in each graph. Right panel. Scatter plots of simulated and observed lake elevations for calibration (b) and validation (d). 
Figure 6 summarizes the results obtained in the analysis of the new water allocation rule under climate change and a climate variability uncertainty scenario. For reference, it shows the different operating levels, the simulated levels under the new rule and those recorded in the April 1980 to March 2014 period.
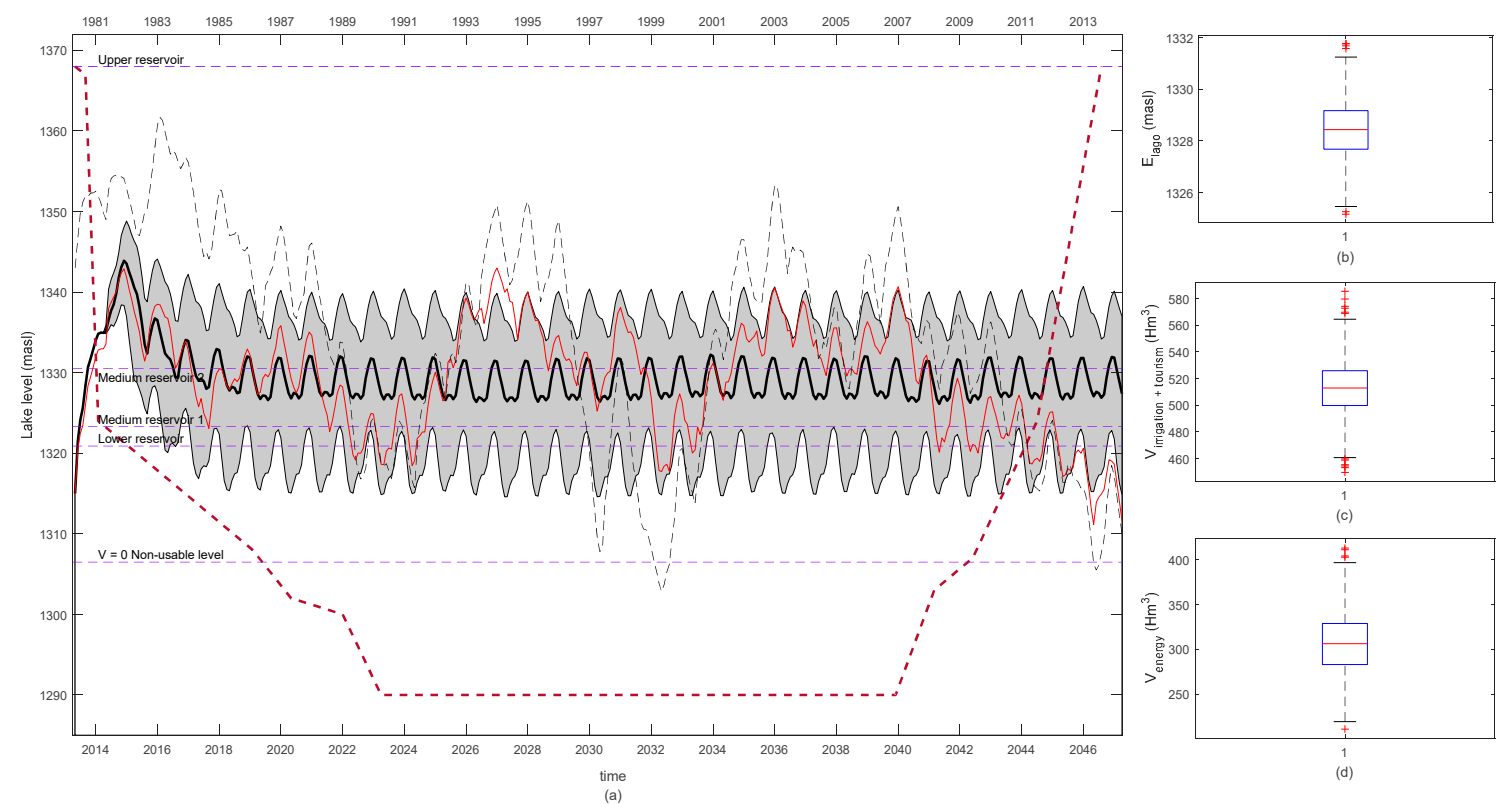

Figure 6. (a) Uncertainty bands (gray area) and median (black line) of simulated scenarios under a climate variability and change scenario and the proposed allocation rule. For reference, a conceptual diagram of the lake is shown in a bold dashed brown line and reference reservoir levels are shown in purple dashed lines. The red line shows simulation results for the level simulations from April 2014 to March 2047 (bottom axis), while the dashed black line shows the recorded levels from April 1980 to March 2014 (top axis). Box plots show lake elevations $\left(\mathrm{E}_{\text {Lake }}\right)(\mathrm{b})$ water allocation for irrigation and tourism (c) and water allocation for energy (d) according to the new rule.

The Laja Lake water levels simulated by the model tend to be higher (median around 1328 m.a.s.l.) than observed during the last five years (1316 m.a.s.l.) (see Figure 6). Water levels under the new water allocation rule are more stable than those observed in the past under the 1958 agreement. A more stable system will likely result in fewer conflicts and a more water-secure system. In addition, the bottom boundary of the uncertainty band in Figure 6 shows that the new rule allows a fast recovery in case of minimum levels as a result of dry years, while the top boundary shows that in case of favorable (wet) hydrological conditions, more water is allocated for energy, maintaining the lake levels between 1323 and 1335 m.a.s.l. Thus, climate variability and change analysis indicates that the new rule will perform adequately in the future.

Climate variability is the main source of uncertainty in the study area [59]. A comparison of the results with simulations that excluded climate change trends (as a test to compare the relative importance of climate change and climate variability) revealed non-significant differences in the uncertainty band, lake levels, and allocations within the simulated period. These results confirm that climate variability plays a primary role in the study area and therefore it must be adequately considered in water planning and management. Additionally, the results indicate that the adaptability of the new rule is adequate to face different sources of variability and uncertainty such as those related to climate variability and change.

Figure 2 shows that since the construction of El Toro hydroelectric plant began in 1958 and its operation in 1973, the lake has never recovered to its natural level (between 1360 and 1368 m.a.s.l. observed between 1956 and 1958). Since 1973, Laja Lake has declined from $3500 \mathrm{Hm}^{3}$ to $600 \mathrm{Hm}^{3}$. 
Such low levels occurred during the extreme drought that affected south-central Chile in 1998 [66] and during the last six years due to the mega-drought [46]. Additionally, low levels coincide with increased water demands as a result of new users (e.g., the Laja-Diguillín canal), population growth, and development (associated with higher standards of living [67,68]). Therefore, a more adaptive water allocation rule became necessary to face not only water needs trends, but climate variability as well.

In drought scenarios (lower boundary of the uncertainty band in Figure 6), the level rises from 1316 to 1323 m.a.s.l. (an increase of $\sim 510 \mathrm{Hm}^{3}$ ) within a year. Meanwhile, the upper boundary of the uncertainty band shows that when the lake reaches high levels such as $\sim 1340$ m.a.s.l. $\left(\sim 3400 \mathrm{Hm}^{3}\right)$ the water allocation also increases, allowing users more water for production purposes. Box plots in Figure $6 c, d$ show that water allocation for irrigation and tourism has little variation, giving users the security needed for their activities. Water allocation for energy has greater variability, however, allowing more water use when it is available.

The water allocation rule ensures a total of $800 \mathrm{Hm}^{3} /$ year on average for irrigation and tourism, while these users have lake water needs of about $515 \mathrm{Hm}^{3} /$ year on average. The positive difference gives farmers more security, especially in dry years, and gives the system absorptive capacity to face dry scenarios, such as those that have been observed in the last 5-7 years. The water from the lake allocated for energy was estimated at $\sim 310 \mathrm{Hm}^{3} /$ year. As the proposed agreement tends to increase the level of the lake, natural seepage also increases, and, therefore, water needs for irrigation supplied by El Toro were lower.

According to the Mao et al. [38] resilience management canvas, the Laja system started from a very resistant position (state 1 in Figure 7) with low water demands, a large amount of water storage, and a forecast for a plentiful hydrologic period (see Garreaud et al. [46]). Increased water demands related to economic development and population growth and increased effects of climate change created a pattern in which storage was constantly decreasing (see Figure 2), thereby moving the system from a resistant stage to a vulnerable stage (state 2 in Figure 7).

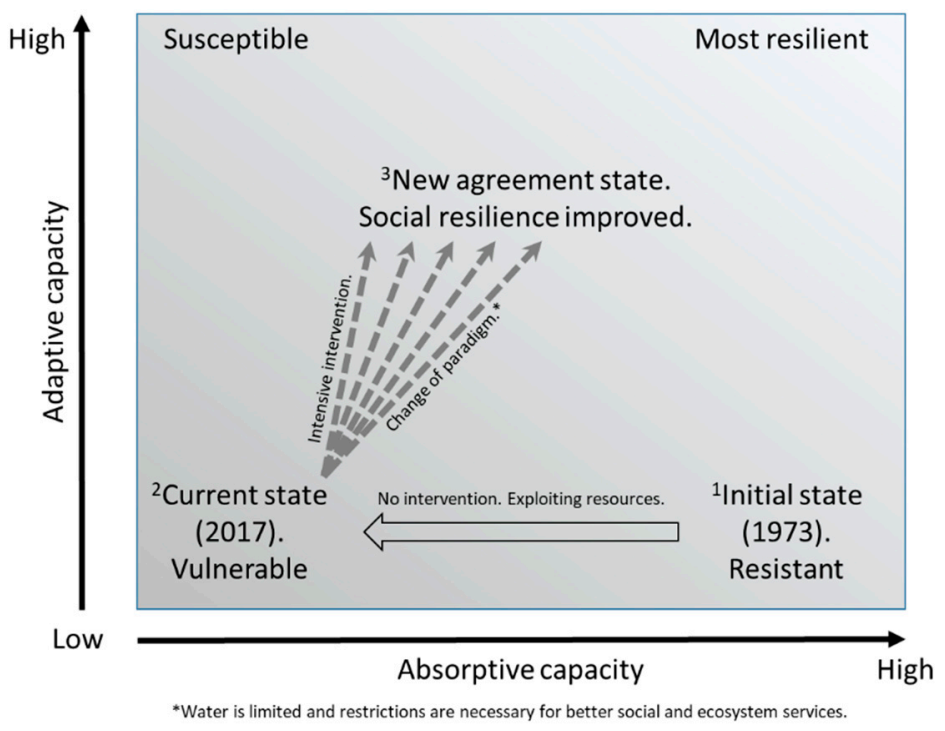

Figure 7. Resilience canvas for the Laja Lake basin, Chile. Canvas proposed by Mao et al. [38].

The Riego-ENDESA [44] agreement did not anticipate hydrological stress scenarios such as those observed within the last 10-15 years. The limited adaptive (or transformative) capacity of the agreement for water allocation led to conflicts among users (in agriculture, industry, and tourism). In addition, the diminished (even eliminated) recovery capacity of the lake (i.e., buffering capacity) due to increased water demands and local water rights legislation restricted adaptive management strategies, further causing conflicts among users. 
The proposed agreement not only increases the average level of Lake Laja, increasing the system's buffering capacity, but also includes an adaptive strategy, restricting use in dry conditions and allowing greater use in wet conditions. With the new agreement forged, the Laja Lake system may be tracking toward a more resilient state (state 3 in Figure 7). In order to reach this agreement, a paradigm change was necessary so users could prioritize intervention strategies that incorporate the socio-hydrological and ecosystem service components into their water rights use plans.

Future adaptations beyond the new agreement and the Polcura diversion could increase lake levels further with a focus on exploration of innovations that could lead to reduced sensitivity of the various sectors dependent on the river flow. For instance, the agricultural sector could consider new crop varieties able to withstand the rising evaporative effects of the anticipated changing climate trends, or the energy sector could supplement hydropower with renewable energy options to relieve pressure on resource constraints. As shown through this analysis, the Laja Lake system could advance toward a more resilient water allocation system by better incorporating absorptive and adaptive capacity into the threatened future supply.

It is important to point out that the new water allocation rule was agreed upon with the participation of local authorities and representatives of water user organizations (irrigation and tourism) and energy organizations. As result of this process, the 2018 agreement [47] was published by the Ministry of Public Works and therefore all the users of Laja Lake must abide by it under the control and supervision of the Chilean Water Authority (Dirección General de Aguas) and Ministry of Public Works.

\section{Conclusions}

The resilience capacity of a hydrological system in southern Chile (the Laja Lake basin) was evaluated. The Laja system began operating under a very non-adaptive rule in a system with high absorptive capacity, i.e., the Laja Lake system was first managed in a resistant position. Over time, after 30 years of water allocation and management, the system continued to operate according to a non-adaptive water allocation rule while having low water storage. As the absorptive capacity changed to low, the resilience state of the system moved to vulnerable. With the new rule, more adaptive water allocation management, along with a slight increase in storage (the absorptive capacity), is being pursued.

Based on a hydrological modeling approach and considering climate variability uncertainty and climate change trends, it was estimated that the new rule will gradually increase the resilience capacity of the Laja Lake system and reduce conflicts among users. The new rule will ensure critical allocations for farming and ecosystem services such as landscaping and allocate extra water for energy in wet hydrological years. In the long run, the new rule will increase the absorptive and adaptive capacities of the system, moving it to a more resilient state than the current one, based on observations in the last six to seven years.

Determining water allocation to various users under complex hydro-climatological patterns and diverse water needs requires adaptive management. The water balance model employed in this analysis demonstrates that the proposed rule is capable of coordination between users with a history of distribution- and climate-induced conflicts. The use of the resilience canvas provides conceptualization, which shows how this system's hydrological component will be crucial in providing system resilience.

Climate change and variability affect most or even all areas of the globe, with a consequent influence on hydrology and water availability. Strict management measures might not permit us to respond to such stressors, as has been seen in the Laja Lake basin in southern Chile. On the other hand, flexible allocation rules, management and governance measures could potentially improve the socio-hydrological resilience of many hydrological systems, making these topics worthy of more active investigation by water resource managers, particularly in regions with variable climates and areas where water stress is an ongoing issue. 
Author Contributions: E.M., C.G., Y.M., J.B., and J.L.A., designed the research and analyses; E.M., J.L.A., and Y.M., analyzed data and performed the analyses; and E.M., C.G., Y.M., J.B., V.P., and J.L.A., designed the paper, developed the discussion, and wrote the paper.

Funding: This research was funded by the CRHIAM, Conicyt/Fondap/15130015 project.

Acknowledgments: The authors thank the Organizaciones de Usuarios del Agua (Water Users Organizations) related to the Laja basin, the Dirección General de Aguas (National Water Directorate), the Coordinador Eléctrico Nacional (National Electric Coordinator), and the Ministry of Public Works of Chile for providing all the data and support for the development of this study.

Conflicts of Interest: The authors declare no conflict of interest.

\section{References}

1. Mishra, A.K.; Singh, V.P. A review of drought concepts. J. Hydrol. 2010, 391, 202-216. [CrossRef]

2. $\mathrm{Xu}, \mathrm{J} . ; \mathrm{Ma}, \mathrm{N}$; Lv, C. Dynamic equilibrium strategy for drought emergency temporary water transfer and allocation management. J. Hydrol. 2016, 539, 700-722. [CrossRef]

3. Muller, M. Adapting to climate change: Water management for urban resilience. Environ. Urban. 2007, 19, 99-113. [CrossRef]

4. Piao, S.; Ciais, P.; Huang, Y.; Shen, Z.; Peng, S.; Li, J.; Zhou, L.; Liu, H.; Ma, Y.; Ding, Y.; et al. The impacts of climate change on water resources and agriculture in China. Nature 2010, 467, 43. [CrossRef]

5. Vörösmarty, C.J.; Green, P.; Salisbury, J.; Lammers, R.B. Global water resources: Vulnerability from climate change and population growth. Science 2000, 289, 284-288. [CrossRef]

6. Gosling, S.N.; Arnell, N.W. A global assessment of the impact of climate change on water scarcity. Clim. Chang. 2016, 134, 371-385. [CrossRef]

7. Fischer, E.M.; Knutti, R. Anthropogenic contribution to global occurrence of heavy-precipitation and high-temperature extremes. Nat. Clim. Chang. 2015, 5, 560. [CrossRef]

8. Grimm, A.M. Interannual climate variability in South America: Impacts on seasonal precipitation, extreme events, and possible effects of climate change. Stoch. Env. Res. Risk A 2011, 25, 537-554. [CrossRef]

9. Li, M.; Guo, P.; Singh, V.P. An efficient irrigation water allocation model under uncertainty. Agric. Syst. 2016, 144, 46-57. [CrossRef]

10. Moradkhani, H.; Sorooshian, S.; Gupta, H.; Houser, P.R. Dual state-parameter estimation of hydrological models using ensemble Kalman filter. Adv. Water Resour. 2005, 28, 135-147. [CrossRef]

11. Renard, B.; Dmitri Kavetski, D.; Kuczera, G.; Thyer, M.; Franks, S.W. Understanding predictive uncertainty in hydrologic modeling: The challenge of identifying input and structural errors. Water Resour. Res. 2010, 46, W05521. [CrossRef]

12. Beven, K. A manifesto for the equifinality thesis. J. Hydrol. 2006, 320, 18-36. [CrossRef]

13. Muñoz, E.; Rivera, D.; Vergara, F.; Tume, P.; Arumí, J.L. Identifiability analysis: Towards constrained equifinality and reduced uncertainty in a conceptual model. Hydrol. Sci. J. 2014, 59, 1690-1703. [CrossRef]

14. Speed, R.; Yuanyuan, L.; Zhiwei, Z.; Le Quesne, T.; Pegram, G. Basin Water Allocation Planning: Principles, Procedures and Approaches for Basin Allocation Planning; UNESCO: Paris, France, 2013.

15. Xiao, Y.; Hipel, K.W.; Fang, L. Incorporating water demand management into a cooperative water allocation framework. Water Resour. Manag. 2016, 30, 2997-3012. [CrossRef]

16. Han, Y.; Huang, Y.F.; Wang, G.Q.; Maqsood, I. A multi-objective linear programming model with interval parameters for water resources allocation in Dalian city. Water Resour. Manag. 2011, 25, 449-463. [CrossRef]

17. Yang, Y.C.E.; Zhao, J.; Cai, X. Decentralized Optimization Method for Water Allocation Management in the Yellow River Basin. J. Water Resour. Plan. Manag. 2011, 138, 313-325. [CrossRef]

18. Yang, Y.S.; Kalin, R.M.; Zhang, Y.; Lin, X.; Zou, L. Multi-objective optimization for sustainable groundwater resource management in a semiarid catchment. Hydrol. Sci. J. 2009, 46, 55-72. [CrossRef]

19. Reis, L.; Bessler, F.; Walters, G.; Savic, D. Water supply reservoir operation by combined genetic algorithm-linear programming (GA-LP) approach. Water Resour. Manag. 2006, 20, 227-255. [CrossRef]

20. Goyal, M.K.; Ojha, C.; Singh, R.; Swamee, P.; Nema, R. Application of ANN, fuzzy logic and decision tree algorithms for the development of reservoir operating rules. Water Resour. Manag. 2013, 27, 911-925. [CrossRef] 
21. Davijani, M.H.; Banihabib, M.E.; Anvar, A.N.; Hashemi, S.R. Multi-objective optimization model for the allocation of water resources in arid regions based on the maximization of socioeconomic efficiency. Water Resour. Manag. 2016, 30, 927-946. [CrossRef]

22. Islam, Z.; Gan, T.Y. Water Allocation Challenges of South Saskatchewan River Basin under the Combined Impacts of Climate Change and El Nino Southern Oscillation. J. Water Resour. Plan. Manag. 2016, 142, 4016039. [CrossRef]

23. Culley, S.; Noble, S.; Yates, A.; Timbs, M.; Westra, S.; Maier, H.R.; Giuliani, M.; Castelletti, A. A bottom-up approach to identifying the maximum operational adaptive capacity of water resource systems to a changing climate. Water Resour. Res. 2016, 52, 6751-6768. [CrossRef]

24. Fiering, M.B. Streamflow Synthesis; Harvard University Press: Cambridge, MA, USA, 1967.

25. Fiering, M.B. Forecasts with varying reliability. J. Sanit. Eng. Div. 1969, 95, 629-644.

26. Fiering, M.B. Alternative indices of resilience. Water Resour. Res. 1982, 18, 33-39. [CrossRef]

27. Fiering, M.B. Estimates of resilience indices by simulation. Water Resour. Res. 1982, 18, 41-50. [CrossRef]

28. Fiering, M.B. Estimating resilience by canonical analysis. Water Resour. Res. 1982, 18, 51-57. [CrossRef]

29. Rodina, L.; Baker, L.A.; Galvin, M.; Goldin, J.; Harris, L.; Manungufala, T.; Musemwa, M.; Sutherland, C.; Ziervogel, G. Water, equity and resilience in Southern Africa: Future directions for research and practice. Curr. Opin. Environ. Sustain. 2017, 26-27, 143-151. [CrossRef]

30. Fiering, M.B.; Holling, C.S. Management and standards for perturbed ecosystems. Agro Ecosyst. 1974, 1, 301-321. [CrossRef]

31. Fiering, M.B. The role of systems analysis in water program development. Nat. Resour. J. 1976, 16, 759-771.

32. Hashimoto, T.; Stedinger, J.R.; Loucks, D.P. Reliability, resiliency, and vulnerability criteria for water resource system performance evaluation. Water Resour. Res. 1982, 18, 14-20. [CrossRef]

33. Pimm, S.L. The complexity and stability of ecosystems. Nature 1984, 307, 321-326. [CrossRef]

34. Quinlan, A.E.; Berbés-Blázquez, M.; Haider, L.J.; Peterson, G.D. Measuring and assessing resilience: Broadening understanding through multiple disciplinary perspectives. J. Appl. Ecol. 2016, 53, 677-687. [CrossRef]

35. Shin, S.; Lee, S.; Judi, D.R.; Parvania, M.; Goharian, E.; McPherson, T.; Burian, S.J. A Systematic Review of Quantitative Resilience Measures for Water Infrastructure Systems. Water 2018, 10, 164. [CrossRef]

36. Asefa, T.; Clayton, J.; Adams, A.; Anderson, D. Performance evaluation of a water resources system under varying climatic conditions: Reliability, resilience, vulnerability and beyond. J. Hydrol. 2014, 508, 53-65. [CrossRef]

37. Chanda, K.; Maity, R.; Sharma, A.; Mehrotra, R. Spatiotemporal variation of long-term drought propensity through reliability-resilience-vulnerability based drought management index. Water Resour. Res. 2014, 50, 7662-7676. [CrossRef]

38. Mao, F.; Clark, J.; Karpouzoglou, T.; Dewulf, A.; Buytaert, W.; Hannah, D. HESS Opinions: A conceptual framework for assessing socio-hydrological resilience under change. Hydrol. Earth Syst. Sci. 2017, 21, 3655-3670. [CrossRef]

39. Holling, C.S. Adaptive Environmental Assessment and Management; Blackburn Press: Caldwell, New York, NY, USA, 1978.

40. Pretty, J.N. Participatory learning for sustainable agriculture. World Dev. 1995, 23, 1247-1263. [CrossRef]

41. Garreaud, R. The Andes climate and weather. Adv. Geosci. 2009, 7, 1-9. [CrossRef]

42. Montecinos, A.; Aceituno, P. Seasonality of the ENSO-related rainfall variability in central Chile and associated circulation anomalies. J. Clim. 2003, 16, 281-296. [CrossRef]

43. Thiele, R.; Moreno, H.; Elgueta, S.; Lahsen, A.; Rebolledo, S.; Petit-Breuilh, M.E. Evolución geológicogeomorfológica cuaternaria del tramo superior del valle del río Laja. Rev. Geol. Chile 1998, 25, 229-253. (In Spanish) [CrossRef]

44. Dirección Nacional de Riego-Empresa Nacional de Electricidad SA. Convenio de Riego Ad-Referéndum sobre la regulación del Río Laja; Dirección Nacional de Riego-Empresa Nacional de Electricidad SA: Santiago, Chile, 1958. (In Spanish)

45. Garreaud, R. Cambio Climático: Bases Físicas e Impactos en Chile. Rev. Tierra Adentro 2011, 93, 1-14. 
46. Garreaud, R.D.; Alvarez-Garreton, C.; Barichivich, J.; Boisier, J.P.; Duncan, C.; Galleguillos, M.; Zambrano-Bigiarini, M. The 2010-2015 megadrought in central Chile: Impacts on regional hydroclimate and vegetation. Hydrol. Earth Syst. Sci. 2017, 21, 6307-6327. [CrossRef]

47. Ministerio de Obras Públicas (MOP). Guía Para la Explotación del Lago Laja; Gobierno de Chile, Ministerio de Obras Públicas, Dirección de Obras Hidráulicas-Endesa: Santiago, Chile, 2018. (In Spanish)

48. Muñoz, E. Desarrollo de un Modelo Hidrológico como Herramienta de Apoyo Para la Gestión del Agua. Aplicación a la Cuenca del Río Laja, Chile. Master's Thesis, Universidad de Cantabria, Santander, Cantabria, Spain, 2010. (In Spanish).

49. Muñoz, E.; Acuña, M.; Lucero, J.; Rojas, I. Correction of Precipitation Records through Inverse Modeling in Watersheds of South-Central Chile. Water 2018, 10, 1092. [CrossRef]

50. Parra, V.; Fuentes-Aguilera, P.; Muñoz, E. Identifying advantages and drawbacks of two hydrological models based on a sensitivity analysis: A study in two Chilean watersheds. Hydrol. Sci. J. 2018, 63, 1831-1843. [CrossRef]

51. Muñoz, E.; Arumí, J.L.; Wagener, T.; Oyarzún, R.; Parra, V. Unraveling complex hydrogeological processes in Andean basins in south-central Chile: An integrated assessment to understand hydrological dissimilarity. Hydrol. Process. 2016, 30, 4934-4943. [CrossRef]

52. Rango, A.; Martinec, J. Revisiting the degree-day method for snowmelt computations. J. Am. Water Resour. Assoc. 1995, 31, 657-669. [CrossRef]

53. Ministerio de Obras Públicas (MOP). Guía Para la Explotación del Lago Laja; Gobierno de Chile, Ministerio de Obras Públicas, Dirección de Obras Hidráulicas-Endesa: Santiago, Chile, 2007. (In Spanish)

54. Ministerio de Obras Públicas (MOP). Guía Para la Explotación del Lago Laj; Gobierno de Chile, Ministerio de Obras Públicas, Dirección de Obras Hidráulicas-Endesa: Santiago, Chile, 2014. (In Spanish)

55. Gupta, H.V.; Kling, H.; Yilmaz, K.K.; Martinez, G.F. Decomposition of the mean squared error and NSE performance criteria: Implications for improving hydrological modelling. J. Hydrol. 2009, 377, 80-91. [CrossRef]

56. Nash, J.E.; Sutcliffe, J.V. River Flow Forecasting Through Conceptual Models, Part I, A Discussion of Principles. J. Hydrol. 1970, 10, 282-290. [CrossRef]

57. Wagener, T.; McIntyre, N.; Lees, M.J.; Wheater, H.S.; Gupta, H.V. Towards reduced uncertainty in conceptual rainfall-runoff modelling: Dynamic identifiability analysis. Hydrol. Process. 2003, 17, 455-476. [CrossRef]

58. Yilmaz, K.; Vrugt, J.A.; Gupta, H.V.; Sorooshian, S. Model calibration in watershed hydrology. In Advances in Databased Approaches for Hydrologic Modeling and Forecasting; Sivakumar, B., Berndtsson, R., Eds.; World Scientific: Hackensack, NJ, USA, 2010; pp. 53-105.

59. Garreaud, R.D.; Vuille, M.; Compagnucci, R.H.; Marengo, J. Present-day South American climate. Palaeogeogr. Palaeoclimatol. Palaeoecol. 2009, 281, 180-195. [CrossRef]

60. Beven, K.; Binley, A. The future of distributed models: Model calibration and uncertainty prediction. Hydrol. Process. 1992, 6, 279-298. [CrossRef]

61. Willmott, C.J.; Matsuura, K. Terrestrial Air Temperature and Precipitation: 1900-2014 Gridded Monthly Time Series, Version 4.01; University of Delaware: Newark, DE, USA, 2014.

62. Muñoz, E.; Arumí, J.L.; Rivera, D.; Montecinos, A.; Bilib, M.; Álvarez, C. Gridded data for a hydrological model in a scarce-data basin. Proc. Inst. Civ. Eng. Water 2012, 167, 249-258. [CrossRef]

63. Thornthwaite, C.W. An approach toward a rational classification of climate. Geogr. Rev. 1948, 38, 55-94. [CrossRef]

64. Moriasi, D.; Arnold, J.; Van Liew, M.; Bingner, R.; Harmel, R.; Veith, T. Model evaluation guidelines for systematic quantification of accuracy in watershed simulations. Trans. ASABE 2007, 50, 885-900. [CrossRef]

65. Kouchi, D.H.; Esmaili, K.; Faridhosseini, A.; Sanaeinejad, S.H.; Khalili, D.; Abbaspour, K.C. Sensitivity of Calibrated Parameters and Water Resource Estimates on Different Objective Functions and Optimization Algorithms. Water 2017, 9, 384. [CrossRef] 
66. Quintana, J. The drought in Chile and La Niña. In Drought Network News (1994-2001); International Drought Information Center and the National Drought Mitigation Center: Lincoln, NE, USA, 2000; p. 71. Available online: http://digitalcommons.unl.edu/droughtnetnews/71 (accessed on 10 May 2018).

67. Valdés-Pineda, R.; Pizarro, R.; García-Chevesich, P.; Valdés, J.B.; Olivares, C.; Vera, M.; Balocchi, F.; Pérez, F.; Vallejos, C.; Fuentes, R.; et al. Water governance in Chile: Availability, management and climate change. J. Hydrol. 2014, 519, 2538-2567. [CrossRef]

68. Meza, F.J.; Vicuña, S.; Jelinek, M.; Bustos, E.; Bonelli, S. Assessing water demands and coverage sensitivity to climate change in the urban and rural sectors in central Chile. J. Water Clim. Chang. 2014, 5, 192-203. [CrossRef] article distributed under the terms and conditions of the Creative Commons Attribution (CC BY) license (http://creativecommons.org/licenses/by/4.0/). 